Роденко Ирина Александровна

\title{
ОЦЕНКА ДЕЙСТВУЮЩЕЙ СИСТЕМЫ ИНВЕСТИЦИОННОГО ПРОЕКТИРОВАНИЯ ПРЕДПРИНИМАТЕЛЬСКОЙ ДЕЯТЕЛЬНОСТИ ТОПЛИВНО-ЭНЕРГЕТИЧЕСКОГО КОМПЛЕКСА РЕСПУБЛИКИ КРЫМ
}

В статье проведен анализ современного состояния топливно-энергетического комплекса (далее - ТЭК) Республики Крым, представлена динамика привлечения инвестиций в ТЭК Республики Крым с 2006 года по 2017 год, дана оценка действующей системе инвестиционного проектирования предпринимательской деятельности (далее - ИППД). Также в статье детализирована организационная структура ТЭКа Республики Крым, выявлены основные проблемы, препятствующие привлечению инвестиций в ТЭК Республики Крым, предложена модель вторичного использования средств инвестиционного проектирования; проанализированы основные показатели деятельности топливно-энергетически компапий, влияющче на устойчивое развитие Республики Крым.

Ключевые слова: топливно-энергетический комплекс, Республика Крым, инвестиционное проектирование предпринимательской деятельности, инвестиции.

\section{Irina Rodenko}

ASSESSMENT OF THE CURRENT SYSTEM OF INVESTMENT PLANNING OF BUSINESS ACTIVITIES OF FUEL AND ENERGY COMPLEX OF THE REPUBLIC OF CRIMEA

The article analyzes the current state of the fuel and energy complex of the Republic of Crimea, presents the dynamics of investment in the fuel and energy complex of the Republic of Crimea since 2006 year till 2017 year, the current system of investment design of business activity was evaluated. Also in the article the organizational structure of fuel and energy Complex of the Republic of Crimea is detailed, the main problems preventing attraction of investments in fuel and energy complex of the Republic of Crimea are revealed, the model of secondary use of means of investment design is offered; the main indicators of activity of the fuel and energy companies influencing sustainable development of the Republic of Crimea.

Key words: fuel and energy complex, Republic of Crimea, investment planning business activities, investments.

Bведениe / Introduction. Республика Крым является регионом перспективного развития, имеющим ряд преимуществ. Транспортно-географическое положение, разнообразный природно-ресурсный и производственно-экономический потенциал определяют основные приоритеты развития региона [1]. С целью реализации колоссальных курортно-рекреационных, транспортных, торгово-коммуникационных и промышленных возможностей Крым должен обладать достаточным мощным ТЭКом.

ТЭК является одной из важнейших отраслей экономики Республики Крым, стабильная работа которого обеспечивает устойчивое развитие других отраслей экономики, а также социальной сферы [4].

Привлечение инвестиций в ТЭК является приоритетным направлением деятельности Правительства Республики Крым, ведь это является основой не только развития отрасли, но и важным элементом обеспечения энергетической безопасности региона [2].

Главной проблемой ТЭКа остается наличие физически и морально изношенных основных производственных фондов (50-70\%).

ТЭК Республики Крым остро испытывает потребность в инвестициях. 
В Федеральной целевой программе «Социально-экономическое развитие Республики Крым и г. Севастополя до 2020 года», государственных программах Республики Крым «Развитие топливно-энергетического комплекса Республики Крым дона 2018-2020 годы» и «Программы газификации населенных пунктов Республики Крым» говорится, что к 2020 году для нормального развития в Республике Крым дополнительно должны быть введены примерно более 1000 МВт мощностей.

По расчетам специалистов, для этого потребуется порядка 25 млрд рублей, а ГУП РК «Крымэнерго», ГУП РК «Черноморнефтегаз» и ГУП РК «Крымгазсети» нуждаются в капиталовложениях на сумму свыше 20 млрд руб. в год, чтобы только модернизировать электростанции, газопроводы, сети электропередач и газораспределительные сети.

Если поставить также и цель увеличения генерирующих мощностей, эта цифра увеличится в несколько раз.

Проблема совершенствования ИППД при долгосрочном планировании развития энергетики - одна из приоритетных управленческих задач, решение которой требует системного подхода.

Энергетика отличается длительным периодом окупаемости вложенных инвестиций. Считается, что примерный срок окупаемости масштабных энергетических проектов составляет в среднем от 5 до 30 лет в зависимости от мощности оборудования и финансовых возможностей рынка продаж электрической и тепловой энергии.

Именно сейчас особенно важно, чтобы государственная политика была направлена на повышение уровня инвестиционной привлекательности российской энергетики для частных инвестиций.

Наиболее привлекательными эксперты отрасли называют: налоговые льготы для инвестиционных вложений в сферу создания новых генерирующих мощностей; государственные гарантии на льготы по кредитам, направленным на развитие энергетического комплекса, а также меры по упорядочиванию законов и нормативных актов, регулирующих деятельность ТЭКа.

Недостаточный объем инвестиций в настоящее время связан с рядом факторов и особенностей функционирования ТЭКа.

К таким факторам, сдерживающим приток инвестиций, нужно отнести нерациональную налоговую политику, неэффективную институционную структуру комплекса; низкий уровень добычи полезных ископаемых.

Положительно влияет на приток реальных инвестиций достаточное бюджетное финансирование отрасли, благодаря которому она динамично развивается.

Соотношения источников инвестиций по каждому типу энергетических компаний определяются на основании вариантов соответствующих инвестиций в структуру собственности в целевой комплекс и в зависимости от вида бизнеса.

Таким образом, распределение по источникам финансирования соответствует распределению инвестиционных рисков между государством и частными инвесторами.

При этом государство концентрирует свои усилия на системообразующих компаниях (ФСК, СО ГидроОГК, «Росэнергоатом»), в то время как основным источником финансирования строительства объектов энергетики являются частные вложения.

Pезультаты и обсуждение/Results and discussion. ТЭК Республики Крым условно можно разделить на подотрасли в сфере электроэнергетики и нефтегазового комплекса.

К электроэнергетике относятся: производство электрической и тепловой энергии за счет традиционных источников энергии; производство электрической и тепловой энергии за счет возобновляемых источников энергии; передача и распределение электрической энергии.

К нефтегазовому комплексу относятся: разведка, освоение месторождений, разработка и добыча природного газа, нефти и газового конденсата; транспортировка и доставка газа потребителю; хранение и перевалка нефтепродуктов, розничная и оптовая торговля моторным и твердым топливом 
Организационная структура топливно-энергетического комплекса Республики Крым представлена на рис. 1 .

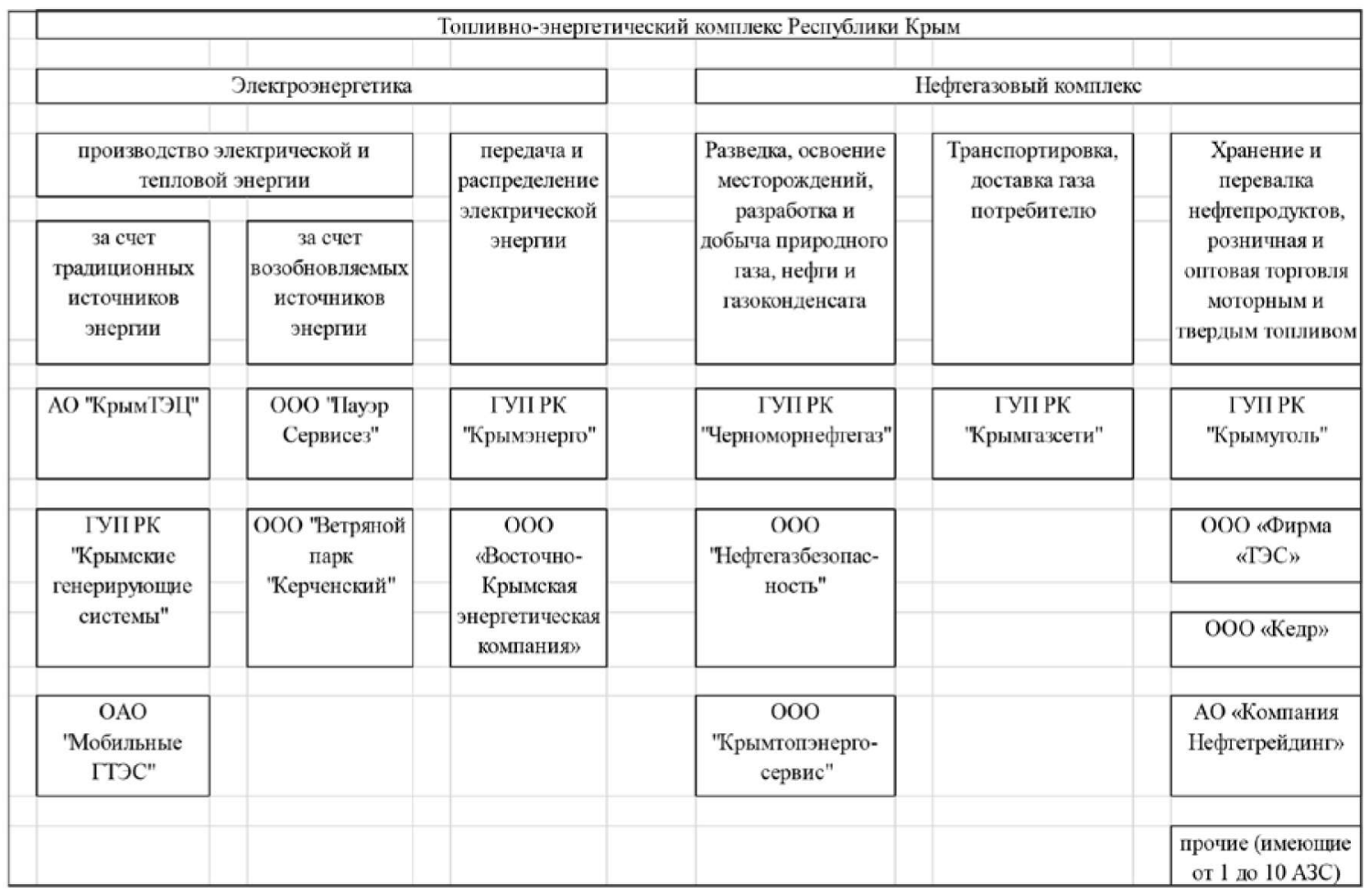

Рис. 1. Организационная структура топливно-энергетического комплекса Республики Крым (Источник: составлено автором)

Главными источниками привлечения инвестиций в ТЭК Республики Крым являются собственные средства предприятий (амортизация, прибыль, тарифы), детализация которых изложена в их инвестиционных программах; долговое финансирование; частные инвестиции (дополнительная эмиссия акций - IPO, SPO, привлечение стратегических инвесторов); государственно-частное инвестирование; федеральный бюджет; региональные источники.

Финансовое формирование инвестиционных программ государственных унитарных предприятий Республики Крым в сфере ТЭКа происходит следующим образом.

В тарифах на газ и электроэнергию отдельной строкой на текущий год Федеральная антимонопольная служба или Государственный комитет по ценам и тарифам Республики Крым утверждают инвестиционную составляющую, источником формирования которой являются сумма амортизационных отчислений предприятий (на балансовую стоимость ежегодно начисляется амортизация, которая должна идти на восстановление производства). В объёме этой суммы предприятия формируют свои инвестиционные программы, которые утверждает Министерство топлива и энергетики Республики Крым.

Тарифная компания на следующий год начинается в мае предыдущего. Проект инвестиционной программы согласовывается министерством, а после утверждения тарифов, приблизительно в декабре, государственные унитарные предприятия Республики Крым корректируют инвестиционные программы по факту утверждённых средств.

Инвестиционные программы содержат перечень мероприятий, со сроками выполнения и необходимым финансированием. 
Если по итогам квартала текущего года возникает экономия в связи с невыполнением мероприятия (например, принято решение о нецелесообразности реализации мероприятия, о включении новых объектов инвестирования в инвестиционную программу; о переносе на более ранний период начала реализации проектов, которые были предусмотрены на последующие годы, или предприятие не успевает выполнить мероприятие в отчетном году, или конкурс не состоялся по каким-либо причинам), то в пределах годовой суммы предприятие может корректировать инвестиционную программу, согласовав ее новую редакцию с Министерством топлива и энергетики Республики Крым. При этом на сумму не освоенных в текущем году средств может быть уменьшена инвестиционная программа в следующем году.

Предпринимательская деятельность в ТЭКе Республики Крым имеет конкурентные преимущества, благодаря которым интерес инвесторов к этой отрасли растет. К таким преимуществам относится:

- эффективная работа станций; топливный баланс; рост спроса на производимую энергию;

- либерализация рынка электроэнергии; стратегическая выгодность размещения активов отрасли;

- привлекательность инвестиционных проектов, наличие опыта руководства отраслью; современность системы управления и ее прозрачность.

Для инвесторов самым важным показателем в работе энергетической компании является структура ее топливного баланса, которая напрямую связана с затратами на генерацию энергии и свидетельствует об эффективности работы компании.

Изменение цен на углеводороды происходит непредсказуемо и, при неизменной структуре топливного баланса, может приводить к ощутимому росту или снижению уровня издержек, предоставляя или, наоборот, лишая конкурентных преимуществ. Именно поэтому данная информация является аб̆солютно конфиденциальной.

Механизм привлечения внешних инвестиций должен быть понятен в первую очередь стратегическому инвестору. Для этого нужно не только создать благоприятные финансовые условия, но и провести необходимую организационную работу:

- разъяснить механизм участия инвестора в управлении энергетическими объектами;

- прописать государственные гарантии по обеспечению эффективности инвестиций;

- принять нормативно-правовые акты по методическому обеспечению возврата инвестиций;

- ужесточить контроль использования инвестиционных ресурсов; вести более «прозрачную» систему бухгалтерского учета;

- создать специализированный институт оценки энергетических инвестиционных проектов;

- организовать единую информационную базу данных проектов и т. д.

Всё это позволяет построить модель, которая раскрывает вторичное использование средств инвестиционного проектирования (рис. 2).

Оценка эффективности капитальных вложений в инновационное строительство или реконструкцию электростанций должна учитывать изменения внешних и внутренних факторов, большинство из которых связаны с неопределенностью. Это норматив дисконтирования, начальные капиталовложения, цена топлива, издержки производства, инфляция, уровень энергопотребления и другие. Поэтому каждое энергетическое предприятие рассматривает одновременно возможную реализацию нескольких инвестиционных проектов. Для определения эффекта от реализации каждого инвестиционного проекта в рассматриваемый период времени (получение прибыли, привлечение инвестиций и т. д.) применяется сравнительный анализ вариантов работы предприятия после сдачи в эксплуатацию объекта инвестирования. Вывод о целесообразности инвестирования проводится по классическим параметрам - в результате расчета NPV, IRR, простого и дисконтируемого сроков окупаемости. Эффективность инвестиционной программы предприятия, состоящей из нескольких инвестиционных проектов, рассматривается как сумма эффектов от каждого проекта. 


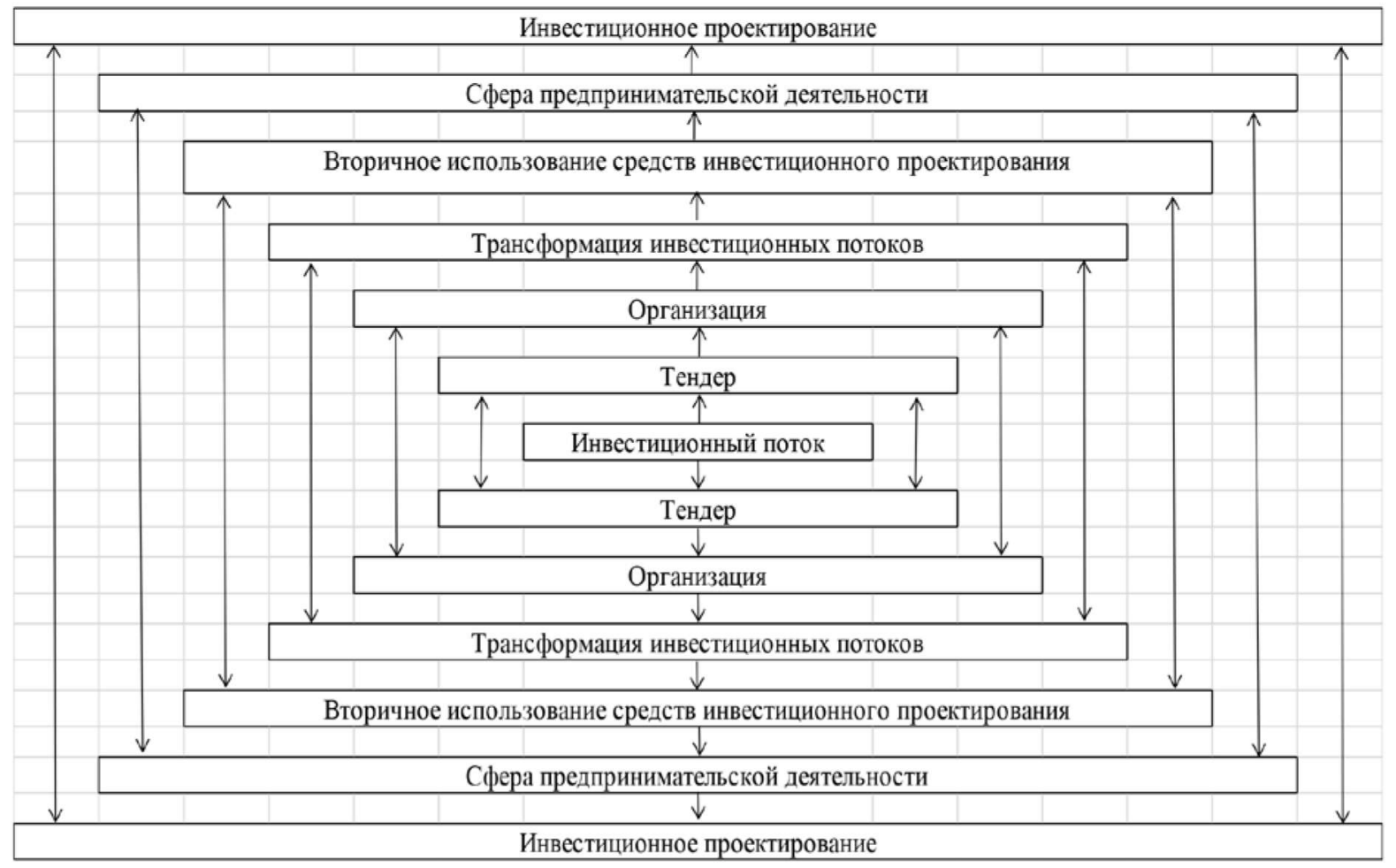

Рис. 2. Модель вторичного использования средств инвестиционного проектирования (Источник: составлено автором)

Однако только экономической оценки эффективности явно недостаточно для получения полной и достоверной информации о том, насколько принимаемый проект будет соответствовать ожиданиям инвестора и других субъектов инвестирования, а также какое действие он окажет на социально-экономическую и экологическую среду региона и на само предприятие. Оценка воздействия вышеуказанных факторов должна учитываться на этапах составления бизнес-плана и анализа его реализации. Это позволит усовершенствовать процесс разработки ИППД в ТЭКе Республики Крым и выбрать альтернативные варианты.

Постоянное поддержание на должном уровне состояния ТЭК позволяет обеспечить энергетическую безопасность в любом регионе, в любой стране и являются дорогостоящим направлением деятельности профильных министерств и ведомств как на федеральном, так и на региональном и местном уровнях.

Поэтому вопросы привлечения значительных средств для осуществления модернизации и строительства электростанций и линий электропередач, газопроводов, проведения крупномасштабных поисковых работ, связанных с добычей и переработкой углеводородного сырья являются стратегически важными вопросами для государства.

На наш взгляд, стоит отметить, что в результате прекращения подачи электроэнергии со стороны Украины в 2014 году предприятия ТЭКа Республики Крым понесли убытки свыше 1,5 млрд руб. ${ }^{1}$ Перечень убытков, понесенных основными предприятиями ТЭКа Республики Крым представлен в таблице.

Санкции в связи с событиями на Украине. Хронология введения [Электронный pecypc]. URL: http://crimea.ria.ru/economy/ 20160306/1103600191.html 
Перечень убытков, понесенных основными предприятиями топливно-энергетического комплекса Республики Крым

\begin{tabular}{|c|c|c|}
\hline $\begin{array}{l}\text { Non, } \\
\text { II/ח }\end{array}$ & Наименование предшриятия & Перечень понесенных убытков \\
\hline 1. & ГУП РК «Черноморнефтегаз» & $\begin{array}{l}\text { • недополученные доходы от реализации природного и ком- } \\
\text { примированного газа; } \\
\text { - дополнительные затраты на приобретение бензина и дизель- } \\
\text { ного топлива для создания резервного запаса; } \\
\text { - ипользование резервных источников питания; } \\
\text { - дополнительные расходы по срочному подключению и запу- } \\
\text { ску электрогенераторных установок; } \\
\text { - предоставление специальной техники для проведения работ } \\
\text { по ликвидации ЧС; } \\
\text { - дополнительные расходы, связанные с закупкой дизель-гене- } \\
\text { раторных установок и др. }\end{array}$ \\
\hline 2. & ГУП РК «Крымгазсети» & $\begin{array}{l}\text { • дополнительные расходы на заправку бензиновых электро- } \\
\text { станций для обеспечения электроэнергией производствен- } \\
\text { ных подразделений; } \\
\text { • } \text { расходы по причине недополученной выгоды в связи с со- } \\
\text { кращением потребления газа потребителями } \\
\end{array}$ \\
\hline 3. & ГУП РК «Крымэнерго» & $\begin{array}{l}\text { • сумма недополученной экономической выгоды по причине } \\
\text { отсутствия электроэнергии }\end{array}$ \\
\hline 4. & $\begin{array}{l}\text { ГУП РК «Крымские } \\
\text { генерирующие системы» }\end{array}$ & $\begin{array}{l}\text { • сумма недополученной экономической выгоды по причине } \\
\text { отсутствия электроэнергии }\end{array}$ \\
\hline 5. & АО «КРЫМТЭЦ» & $\begin{array}{l}\text { • сумма недополученной экономической выгоды по причине } \\
\text { отсутствия электроэнергии }\end{array}$ \\
\hline
\end{tabular}

Источник: составлено автором.

Основными проблемами, которые ограничивают внешнеэкономическую и межрегиональную деятельность в ТЭКе Республики Крым, являются санкции зарубежных стран против России и Республики Крым, ставшие основным препятствием для привлечения иностранных инвестиций.

Набор санкций, введенных США, Европейским союзом, Украиной, факт непризнания Республики Крым субъъектом Российской Федерации различными странами мира приводят к тому, что объем иностранных инвестиций становится ограниченным [4]. При сохранении санкций необходимо широкое участие государства в развитии ТЭКа полуострова [10]. Санкции направлены на ключевые отрасли экономики, в том числе и ТЭК, конкретнее - на нефтегазовую отрасль, так как основные поступления в бюджет Республики Крым приносит деятельность ГУП РК «Черноморнефтегаз) [1].

На самом деле санкции, которые были введены против основного нефтегазодобывающего предприятия ГУП РК «Черноморнефтегаз», не отразились на его развитии. Проблемные вопросы, связанные с поставками оборудования и комплектующих, произведенных в странах ЕС и США были решены с помощью импортозамещения [2].

ГУП РК «Черноморнефтегаз» - многоотраслевое предприятие, которое выполняет работы, связанные с разведкой и разработкой нефтегазовых месторождений в Азовском и Черном морях, занимается хранением и транспортировкой природного газа.

Основные показатели деятельности ГУП РК «Черноморнефтегаз», влияющие на устойчивое развитие Республики Крым, отражены на рис. 3 и 4. 


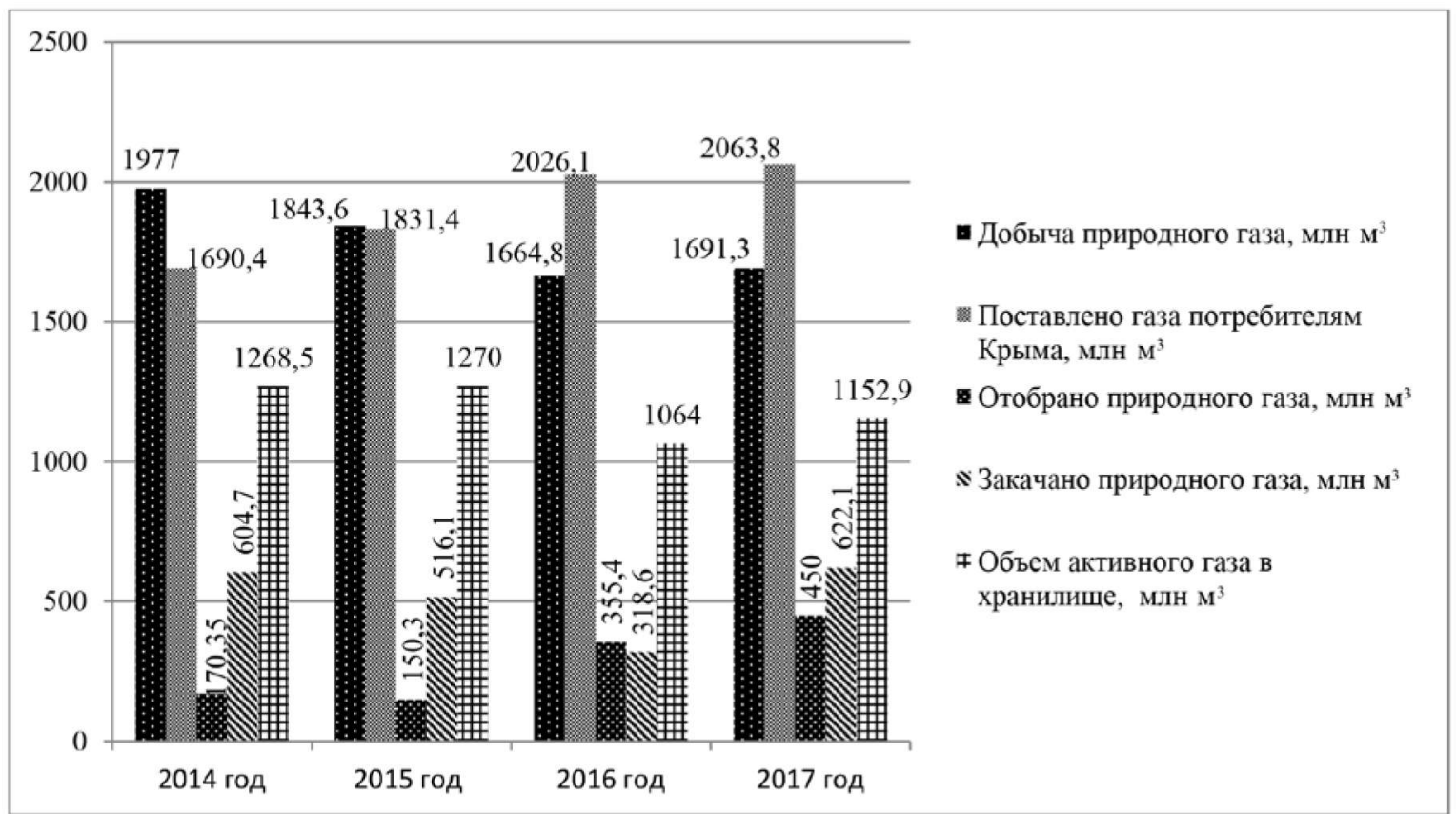

Рис. 3. Основные показатели деятельности ГУП РК «Черноморнефтегаз», влияющие на устойчивое развитие Республики Крым, млн $\mathbf{M}^{3}$

(Источник: составлено автором)

На предприятии успешно функционирует комплексная инфраструктура, приспособленная к специфическим условиям морской нефтегазодобычи. 16 месторождений углеводородов, являющиеся производственными объектами ГУП РК «Черноморнефтегаз», подразделяются на 5 газоконденсатных (Голицынское, Западно-Октябрьское, Одесское, Шмидта, Штормовое); 8 газовых (Архангельское, Безымянное, Восточноказантипское, Джанкойское, Задорненское, Северо-Керченское, Северобулганакское, Южно-Голицынское); 1 нефтегазовое (Карлавское); 2 нефтяных (Семеновское и Субботина). При этом из 16 месторождений углеводородов 10 морских: Архангельское, Штормовое, Безымянное, Одесское, Шмидта, Южно-Голицынское, Субботина (шельф Черного моря) Восточноказантипское, Северобулганакское, Северо-Керченское (шельф Азовского моря).

Падение добычи природного газа в 2015-2016 годах связано с выработкой ресурса на газовых и газоконденсатных месторождениях и обусловлено снижением пластового давления на месторождениях, т. к. большая часть из них находится в стадии падающей добычи.

Объёмы газа в Глебовском подземном хранилище позволяют обеспечивать стабильное газоснабжение потребителей в отопительные сезоны.

Снижение объьмов добычи нефти в 2016 году допущено ГУП РК «Черноморнефтегаз» в связи с выработкой ресурса на нефтяных месторождениях.

ГУП РК «Черноморнефтегаз» планирует наращивать добычу и прирост ресурсной базы углеводородов путем бурения первой разведочной скважины на структуре Гордиевича и еще двух разведочных скважин, запасы газа которых оцениваются в 30-100 млрд м². $^{3}$.

Снижение объемов добычи нефти в 2015-2017 годах допущено ГУП РК «Черноморнефтегаз» в связи с выработкой ресурса на нефтяных и газоконденсатных месторождениях.

ГУП РК «Черноморнефтегаз» планирует возобновление программы разведки ресурсов нефти на Прикерченском участке шельфа Черного моря (месторождение Субботина, структуры Абиха и Лычагина), а также выполнение проектных работ по Поворотному газоконденсатному месторождению. Планируется бурение трех скважин и обустройство месторождения. 


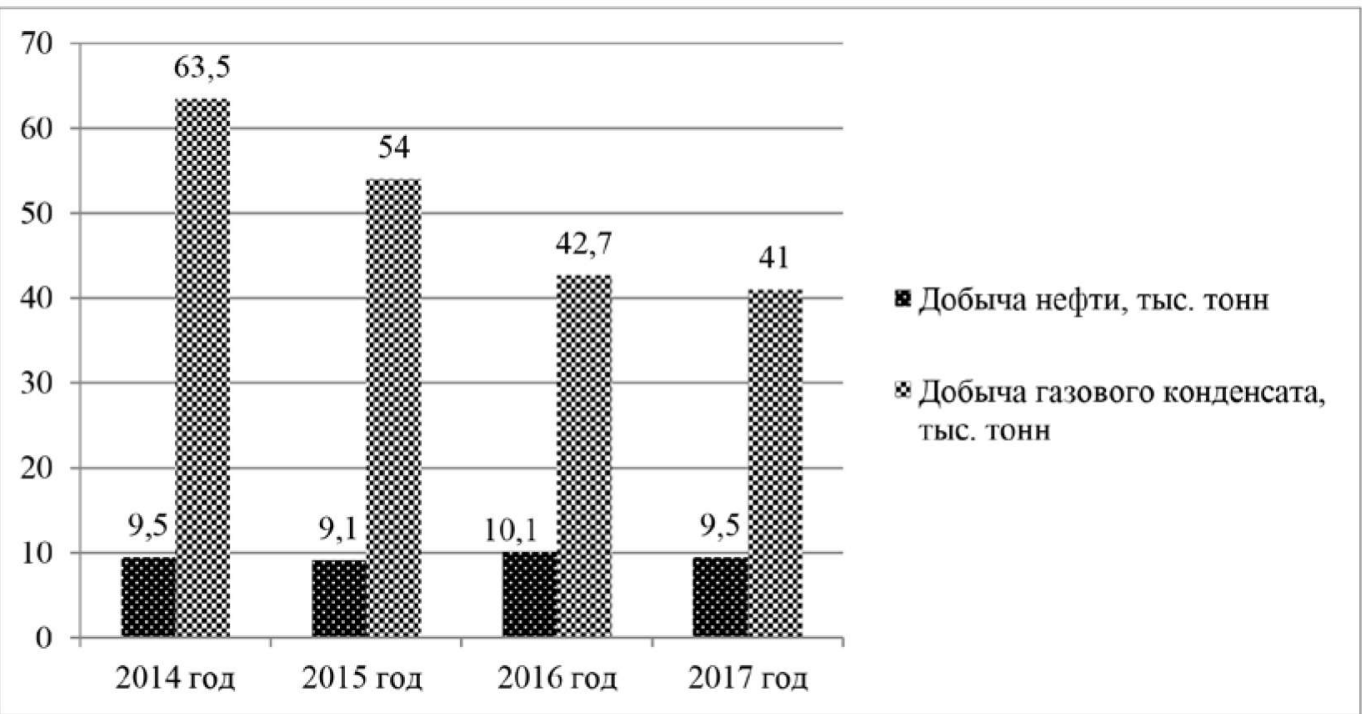

Рис. 4. Основные показатели деятельности ГУП РК «Черноморнефтегаз», влияющие на устойчнвое развитие Республики Крым, тыс. т

(Источник: составлено автором).

Следует отметить, что западные санкции не направлены на электроэнергетику, ни одно энергетическое предприятие не попало под санкции [5].

На рис. 5 представлена динамика привлечения инвестиций в ТЭКе Республики Крым с 2006 года по 2017 год.

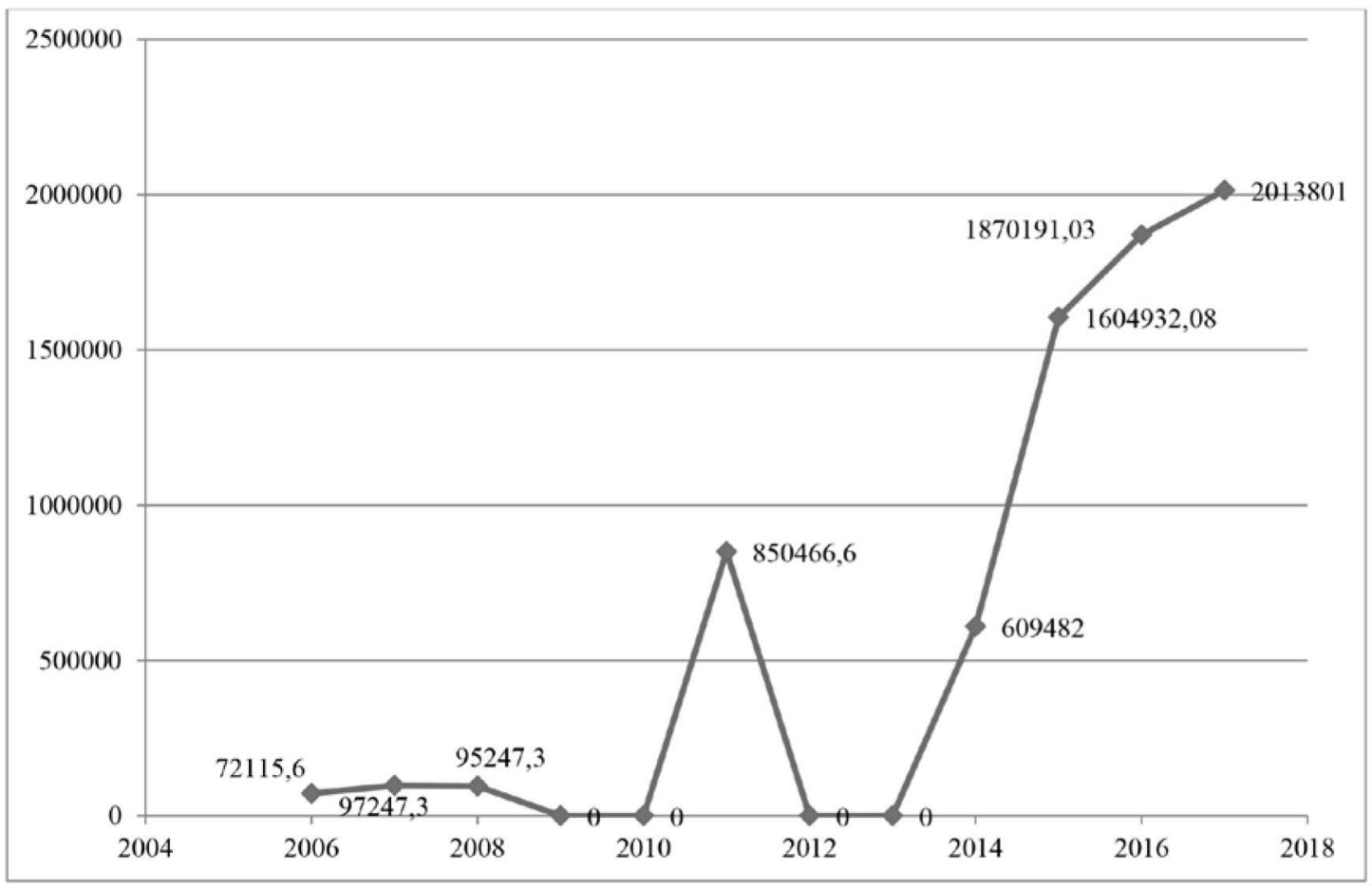

Рис. 5. Динамика привлечения инвестиций в топливно-энергетический комплекс Республики Крым, тыс. руб. (Источник: составлено автором) 
Денежные средства направлялись следующим образом.

В 2006 году профинансированы мероприятия по строительству газопроводов-отводов и газификации населенных пунктов, в первую очередь сельских, в размере 72 115,6 тыс. руб. (18 977,8 грн.).

В 2007 году профинансировано 97 247,3 тыс. руб. (25 591,4 грн. - субвенция на мероприятия по энергосбережению).

В 2008 году объъм финансирования составил 95 258,4 тыс. руб. (25 068 грн. - субвенция на мероприятия по энергосбережению).

В 2009 году финансирование не осуществлялось.

В 2010 году финансирование не осуществлялось.

В 2011 году профинансировано 850 466,6 тыс. руб. (223 807 грн. - на реализацию мероприятий Государственной целевой экономической программы энергоэффективности и развития сферы производства энергоносителей из возобновляемых источников энергии и альтернативных видов топлива на 2010-2015 годы).

В 2012 году финансирование не осуществлялось.

В 2013 году финансирование не осуществлялось.

В 2014 году финансирование 609482 тыс. руб.

В 2015 году финансирование составило 1604932,08 тыс. руб.

В 2016 году профинансировано 1870191,03 тыс. руб.

В 2017 году финансирование составило 2013801 тыс. руб.

В целом за 4 года (с 2014 по 2017 годы):

- газифицировано 40 населённых пунктов Республики Крым;

- ведутся работы по строительству Таврической и Балаклавской ТЭС в Симферопольском районе и вблизи г. Севастополя, ввод в эксплуатацию которых запланирован на 2018 год (общая проектная мощность двух новых электростанций составляет $940 \mathrm{MBT}$ );

- ведутся работы по увеличению мощности Сакской ТЭЦ АО «КрымТЭЦ» на 120 МВт (после завершения пусконаладочных работ, станция будет выдавать дополнительно 90 МВт электроэнергии);

- построен энергетический мост, благодаря которому Крым получает до 800 МВт электроэнергии;

- введён в эксплуатацию магистральный газопровод «Краснодарский край - Крым». Республика Крым стала частью единой газотранспортной системы России.

Реализация Государственной программы республики по газификации населённых пунктов на 2018-2022 годы предполагает газификацию 128 населённых пунктов и 48 тысяч индивидуальных домов и квартир. Планируется построить 149 км магистральных газопроводов и отводов, около 600 км межпоселковых газопроводов, около 1500 км уличных сетей, 18 газораспределительных станций. Планируемый объём финансирования программы составит почти 20 млрд 600 млн рублей.

В сфере газоснабжения принят ряд социально значимых решений, которые затронули десятки и сотни тысяч крымчан.

Цены на установку газовых счётчиков снижены на $20 \%$. Срок замены счётчиков продлён до 2021 года. Установлена предельная цена на сжиженный газ для бытовых нужд - не более 760 руб. за баллон.

Обслуживанием внутридомового газового оборудования с 2017 года занимается только ГУП РК «Крымгазсети». Это касается и проверки дымовентиляционных каналов. Частных компаний, задирающих цены, на этом рынке больше нет.

Ещё одной острой социальной проблемой является восстановление и модернизация сетей уличного освещения: порядка 70 \% инженерных сетей инфраструктуры наружного освещения изношены и нуждаются в замене или обновлении. 
В Республике Крым действует программа энергосбережения и повышения энергетической эффективности на 2018-2019 годы и на перспективу до 2020 года, мероприятия которой также является предметом инвестирования.

В рамках программы предусмотрены работы по восстановлению и модернизации наружного освещения как отдельно взятых улиц, так и сельских поселений в 20 муниципальных образованиях республики.

Заключение /Conclusion. ТЭК Республики Крым является каркасом экономики полуострова. Обеспечение и поддержание стабильного газо- и электроснабжения населения, а также промышленных предприятий республики является первостепенной задачей.

Кардинальные преобразования, произошедшие в ТЭКе Республики Крым за последние 4 года, требуют формирования соответствующих программ развития, в основе которых лежит инвестиционная составляющая.

Такими программами развития выступают:

- программа федерального уровня - Федеральная целевая программа «Социально-экономическое развитие Республики Крым и г. Севастополя до 2020 года»

- программы регионального уровня - государственные программы Республики Крым «Развитие топливно-энергетического комплекса Республики Крым дона 2018-2020 годы» и «Программа газификации населенных пунктов Республики Крым»

- $\quad$ инвестиционные программы государственных унитарных предприятий Республики Крым в сфере ТЭКа.

Как бы это ни парадоксально звучало, но предпринимательская деятельность в ТЭКе представлена не только акционерными обществами, но и государственными унитарными предприятиями Республики Крым, которые, реализуя свои инвестиционные программы, модернизируют и развивают энергетический и нефтегазовый комплекс.

За 8 лет (с 2006 по 2013 годы) было освоено 1115 088,0 тыс. рублей (с коэффициентом пересчета цен в рубли, равным 3,8$)$, что на $43,9 \%, 67,7 \%$ и $80,6 \%$ меньше, чем было освоено за 2015 год, 2016 год и 2017 годы соответственно.

ИППД подтверждает, что предпринимательская деятельность является престижной и экономически выгодной, но при этом характеризуется высокой степенью сложности, социальной ответственности и рискованности во многих аспектах.

Кроме того, энергетические объекты изначально являются особо капиталоемкими, ремонтоемкими, а инвестиции в энергетику имеют достаточно длительные сроки окупаемости. В этой отрасли всегда существуют неблагоприятные для инвесторов соотношения между продажной ценой ресурса (электроэнергии, газа, бензина и т. д.) и стоимостью основного капитала.

Положение усугубляется высоким уровнем физического износа основного капитала. Поэтому важно при разработке методик оценки эффективности ИППД учитывать особенности энергетической отрасли, позволяюшие наиболее объективно оценивать возможности и планировать инвестиции в отрасль для обеспечения развития энергетической системы региона.

Также хотелось бы отметить, что влияние санкций на энергетическую безопасность Республики Крым несущественно [5]. ТЭК Республики Крым продолжает стабильно работать и развиваться.

ИППД направлено на решение текущих основных проблем функционирования ТЭКа Республики Крым, связанных:

- о отсутствием достаточных собственных мощностей для растущих потребностей Республики Крым;

- высоким уровнем износа электросетевого и газового хозяйства, что влечет за собой высокий уровень потерь электроэнергии и газа;

- низким уровнем газификации сельской местности (49,2\%). 
С помощью реализации вышеуказанных мероприятий, учитывая, что Республика Крым входит в десятку регионов-лидеров в России по уровню модернизации сферы ТЭКа и внедрению энергосберегающих технологий, полуостров будет полностью обеспечен надежным и бесперебойным электро- и газоснабжением потребителей как при сохранении и / или усилении санкций, так и без них.

\section{ЛИТЕРАТУРА И ИНТЕРНЕТ-РЕСУРСЫ}

1. Об утверждении государственной программы Республики Крым «Развитие топливно-энергетического комплекса Республики Крым на 2015-2017 годы»: Постановление Совета министров Республики Крым от 09.04.2015 № 186 [Электронный ресурc]. URL: https://rk.gov.ru/rus/file/pub/pub_242913.pdf.

2. Бакуменко М. А. О мерах по активизации инвестиционных процессов на территории Республики Крым // Анализ, моделирование, управление, развитие социально-экономических систем: сборник научных трудов X Международной школы-симпозиума АМУР-2016 (Симферополь - Судак, 12-21 сентября 2016) / под ред. А. В. Сигала. Симферополь: КФУ им. В. И. Вернадского, 2016. С. 22-29.

3. Блинов А. О. Формирование систем инновационного предпринимательства в Российской Федерации // Вестник Научно-исследовательского центра корпоративного права, управления и венчурного инвестирования Сыктывкарского государственного университета [Электронный ресурс]. URL: http://koet.syktsu.ru/vestnik/2006/2006-3/4.htm.

4. Оборин М. С., Роденко И. А. Концепция реализации инвестиционной деятельности в сфере топливно-энергетического комплекса Республики Крым // Сервис в России и за рубежом. 2017. Т. 11. № 7 (77). C. 113-125.

5. Официальный сайт AO «КРЫМТЭЦ» [Электронный ресурc]. URL: http://krimtec.ru.

6. Официальный сайт ГУП РК «Крымгазсети» [Электронный ресурc]. URL: http://www.gas.crimea.com/

7. Официальный сайт ГУП PК «Крымские генерирующие системы» [Электронный ресурс]. URL: http://www.energysystem-crimea.ru.

8. Официальный сайт ГУП РК «Крымэнерго» [Электронный ресурc]. URL: http://gup-krymenergo. crimea.ru.

9. Официальный сайт ГУП РК «Черноморнефтегаз» [Электронный ресурc]. URL: http://gas.crimea.ru

10. Роденко И. А. Особенности развития топливно-энергетического комплекса Республики Крым в условиях новой индустриализации» // Методология устойчивого экономического развития в условиях новой индустриализации: сборник трудов Международной научной конференции (г. Симферополь, 6-7 октября, 2016 г.). Симферополь, 2016. С. 563-566.

11. Роденко И. А. Формирование устойчивого развития топливно-энергетического комплекса Республики Крым // Устойчивое развитие науки и образования. 2017. № 5. С. 14-18.

12. Krupp F., Horn M. Earth: The Sequel: The Race to Reinvent Energy and Stop Global Warming. N.Y., 2008.

13. Zilberstein, O. (2014, May 5). Assesment of the energy industry role in structure of the Russian economy and formation of national power safety indicators. Economy and modern management: theory and practice: compendium of reports of 32nd international scientific-practical conference. URL: http://sibac.info/14671.

\section{REFERENCES AND INTERNET RESOURCES}

1. Ob utverzhdenii gosudarstvennoi programmi Respubliki Krym «Razvitie toplivno-energeticheskogo kompleksa Respubliki Krym na 2015-2017 gody» ("About approval of the state program of the Republic of Crimea «Development of fuel and energy complex of the Republic of Crimea for 2018-2020»: Postanovlenie Soveta ministrov Respubliki Krym. 09.04.2015 № 186 [Elektronnyi resurs]. URL: https://rk.gov.ru/rus/file/ pub/pub_242913.pdf.

2. Bakumenko M. A. O merakh po aktivizatsii investitcionnikh protsessov na territorii Respubliki Krym (About measures to intensify the investment processes in the territory of the Republic of Crimea) // Analiz, modelirovanie, upravlenie, razvitie sotsial'no-economicheskikh sistem: sbornik nauchnykh trudov X Mezhdunarodnoi shkoly-simpoziuma AMUR-2016 (Simferopol - Sudak, 12-21 September 2016) / pod red. A. V. Segal. Simferopol: KFU im. V. I. Vernadskogo, 2016. Pp. 22-29. 
3. Blinov A. O. Formirovanie sistem innovatcionnogo predprinimatel'stvav Rossiiskoi Federatsii (Formation of the system of innovative entrepreneurship in the Russian Federation) // Vestnik nauchno-issledovatel'skogo korporativnogo prava, upravleniya i venchurnogo investirovaniya Syktyvkarskogo gosudarstvennogo universiteta [Elektronnyi resurs]. URL: http://koet.syktsu.ru/vestnik/2006/2006-3/4.htm.

4. Oborin M. S., Rodenko I. A. Koncepciya realizatcii investitcionnoi deyatelnosti v sfere toplivno-energeticheskogo kompleksa Respubliki Krim (The Concept of investment activities in the field of fuel and energy complex of the Republic of Crimea) // Servis v Rossii I za rubezhom. 2017. T. 11. № 7 (77). Pp. 113-125.

5. Ofitsial'nyi sait OAO «KRYMTETC» [Elektronnyi resurs]. URL: http://krimtec.ru.

6. Ofitsial'nyi sait GUP RK «Krymgazseti» [Elektronnyi resurs]. URL: http://www.gas.crimea.com.

7. Ofitsial'nyi sait GUP RK «Krymskie generiruyushie sistemi» [Elektronnyi resurs]. URL: http://www. energysystem-crimea.ru.

8. Ofitsial'nyi sait GUP RK «Krymenergo» [Elektronnyi resurs]. URL: http://gup-krymenergo.crimea.ru.

9. Ofitsial'nyi sait GUP RK «Chernomorneftegaz» [Elektronnyi resurs]. URL: http://gas.crimea.ru.

10. Rodenko I. A. Ossobennosti razvitiya toplivno-energeticheskogo kompleksa Respubliki Krym v usloviyakh novoi industrializatcii (Features of development of fuel and energy complex of the Republic of Crimea in the conditions of new industrialization) // Metodologiya ustojchivogo ekonomicheskogo razvitiya $\mathrm{v}$ usloviyakh novoi industrializatcii: sbornik trudov Mezhdunarodnoi nauchnoi konferentcii (Simferopol, October 6-7, 2016). Simferopol', 2016. Pp. 563-566.

11. Rodenko I. A. Formirovanie ustojchivogo razvitiya toplivno-energeticheskogo kompleksa Respubliki Krym (Formation of sustainable development of fuel and energy complex of the Republic of Crimea) // Ustojchivoe razvitie nauki i obrazovaniya. 2017. № 5. Pp. 14-18.

12. Krupp F., Horn M. Earth: The Sequel: The Race to Reinvent Energy and Stop Global Warming. N.Y., 2008.

13. Zilberstein, O. (2014, May 5). Assesment of the energy industry role in structure of the Russian economy and formation of national power safety indicators. Economy and modern management: theory and practice: compendium of reports of 32nd international scientific-practical conference. Retrieved from http://sibac. info/14671.

\section{СВЕДЕНИЯ ОБ АВТОРЕ}

Роденко Ирина Александровна, аспирант, ФГАОУ ВО «Крымский федеральный университет имени В. И. Вернадского», rodenko.irina@bk.ru.

\section{INFORMATION ABOUT AUTHOR}

Irina Rodenko, post graduate student, V. I. Vernadsky Crimean Federal University. E-mail: rodenko.irina@bk.ru 